STRUČNI ČLANAK

Srdan Tolpa*

\title{
IZMENE I DOPUNE ZAKONA O PARNIČNOM POSTUPKU
}

\section{UvoD}

1.1. Zakon o parničnom postupku, kao osnovni izvor građanskog procesnog prava, reguliše materiju parničnog sudskog postupka čiji je zadatak zaštita građanskih subjektivnih prava i pravnih ovlašćenja. Norme koje postavljaju okvire parničnom postupku nisu dispozitivne već imperativne norme, ius cogens. Sud i stranke su dužni da ih kao takve primenjuju, kao i da svoje parnične radnje prema njima upravljaju. Manevarski prostor u primeni pomenutih procesnih normi, stranke imaju jedino u slučaju da im to zakon izričito dozvoli. ${ }^{1}$

1.2. U slučaju donošenja zakona o izmenama i dopunama postojećeg zakona, postavlja se pitanje koji će se od ta dva zakona primeniti na konkretan spor. Pitanja važenja procesnog prava ratione temporis regulišu intertemporalne odredbe, gde možemo razlikovati dve situacije. Prva situacija postoji onda kada je parnični postupak pokrenut nakon što se novi zakon počeo primenjivati. U ovom slučaju nesumnjivo će se primeniti odredbe zakona važećeg u trenutku pokretanja postupka. Situacija u kojoj je novi zakon počeo da se primenjuje, a parnica je već započela po pravilima prethodnog, malo je kompleksnija. U većini ovakvih slučajeva predviđa se neposredna primena odredaba novog zakona i na postupak u toku, osim ako se prelaznim odredbama zakona ne predvidi drugačije rešenje. Zakonodavac ne predviđa neposrednu primenu po donošenju pravnosnažne prvostepene sudske odluke, kao i u postupku po vanrednim pravnim lekovima, u slučaju kad je postupak pokrenut pre stupanja novog zakona na scenu. U ovim slučajevima postupak će se voditi po pravilima starog zakona. Samostalnim odredbama člana 55. Zakona o

\footnotetext{
* Student Pravnog fakulteta Univerziteta Union u Beogradu

1 U članu 6. Zakona o izmenama i dopunama Zakona o parničnom postupku (dalje u tekstu u fusnotama: Zakon o izmenama i dopunama ZPP-a) stranke se mogu sporazumeti da imovinskopravne sporove koji prelaze 50.000 evra sudi takođe sudija pojedinac, osim ako ih zakon u posebnim slučajevima u tome ne ograniči. Vidi: $Z a-$ kon o izmenama i dopunama Zakona o parničnom postupku, objavljen u „Službenom glasniku RS“, br. 111/09, od 29. decembra 2009. godine.
} 
izmenama i dopunama ZPP-a propisano je da se postupci započeti pre stupanja na snagu Zakona o izmenama i dopunama ZPP-a okončavaju po odredbama ovog zakona. Izuzetak je predviđen u slučaju izjavljivanja revizije. ${ }^{2}$

1.3. Važeći Zakon o parničnom postupku (u daljem tekstu: ZPP) stupio je na snagu 22. februara 2005. godine. ${ }^{3}$ Izmene i dopune ZPP-a izvršene su u decembru 2009. godine. Cilj donošenja izmena i dopuna Zakona su jezičko uskladivanje, modifikacije određenih pravila i popunjavanje pravnih praznina.

\section{ZAKON O IZMENAMA I DOPUNAMA ZAKONA O PARNIČNOM POSTUPKU}

Zakon o izmenama i dopunama Zakona o parničnom postupku (u daljem tekstu: Zakon) stupio je na snagu 29. decembra 2009. godine. S obzirom na sadržinu Zakona i prirodu uvedenih izmena, možemo izvršiti podelu na: terminološke izmene, izmene limita novčanih vrednosti, izmene koje se odnose na postupak i izmene koje se odnose na postupak po pravnim lekovima. ${ }^{4}$

\section{TERMINOLOŠKE IZMENE}

1.1. Pored uvođenja i izmene procesnih instituta koji se odnose na parnični postupak, prilikom donošenja novog zakona javila se potreba njegovog terminološkog usklađivanja sa važećim propisima. Od momenta stupanja na snagu ZPP-a, doneti su neki novi propisi, dok je nekolicina pretrpela izmene koje su se reflektovale i na ZPP. Pored prostog usklađivanja koje se postiglo Zakonom, izmenama su rešeni praktični problemi koji su se javljali u praksi zbog formulacije samih odredaba, a unete su i neke novine koje značajno utiču na drugačije regulisanje samog toka postupka.

1.2. S obzirom na teritorijalne promene koje su potvrđene Ustavom iz 2006. godine, izraz „Državna zajednica Srbije i Crne Gore“ zamenjen je izrazom „Republika Srbija“, a „teritorijalna autonomija“ rečima „autonomna pokrajina“. Takođe je postojala potreba da se terminološki usklade nazivi sudova nakon reforme sudstva i donošenja Zakona o uređenju sudova, te su „trgovinski sudovi“ zamenjeni „privrednim“, „viši sudovi“ „drugostepenim“

2 Predviđeno je da o revizijama koje su izjavljene pre stupanja na snagu Zakona o izmenama i dopunama ZPP-a odlučuje Vrhovni kasacioni sud u veću sastavljenom od trojice sudija po pravilima postupka koja su važila do dana stupanja na snagu ovog zakona. Ovo pravilo predstavlja suštinski promenu zakonskih pravila u pogledu sastava veća i odlučivanja o već izjavljenim revizijama. Vidi: Komentar Zakona o izmenama $i$ dopuna Zakona o parničnom postupku, „Službeni glasnik RS“, br. 111/09, Paragraf net.

3 Zakon o parničnom postupku objavljen je u „Službenom glasniku RS“, br. 125/04 od 22. novembra 2004. godine.

4 Vidi: Komentar Zakona o izmenama i dopunama ZPP-a („Službeni glasnik RS“, br. 111/09). 
itd. Izvršeno je usklađivanje i sa porodičnopravnim poropisima - reči „bračni drugovi“ zamenjene su rečju „supružnici“, reč „supružnik“ rečju „partner“, a reč „staralac“ rečju „staratelj“.

1.3. Pored proste terminološke zamene, dodavanjem određenih izraza postiglo se bolje razumevanje smisla tog dela zakonskog teksta, što znatno olakšava tumačenje i primenu zakona.

\section{IZMENE LIMITA NOVČANIH VREDNOSTI}

2.1. Pored instituta direktno vezanih za tok postupka, novim zakonom izvršene su izmene visine iznosa koji opredeljuju mogućnost izjavljivanja revizije, sastava suda u konkretnom sporu, kao i definisanje spora male vrednosti. Značajna novost je i to što su novčani iznosi određeni u dinarskoj protivvrednosti prema srednjem kursu Narodne banke Srbije na dan podizanja tužbe.

2.2. Zakonskim normama koje regulišu pitanje revizije predviđeno je da revizija nije dozvoljena u imovinskopravnim sporovima kad se tužbeni zahtev odnosi na utvrđenje prava svojine na nepokretnostima, potraživanje u novcu, predaju stvari ili izvršenje neke druge činidbe ako vrednost predmeta spora pobijenog dela drugostepene presude ne prelazi dinarsku vrednost od 100.000 evra prema srednjem kursu Narodne banke Srbije na dan podnošenja tužbe. Limit za reviziju posebno je postavljen u privrednim sporovima i sada iznosi 300.000 evra u dinarskoj protivvrednosti na dan podnošenja tužbe. Ovim je postignuto smanjenje mogućnosti revizijskog preispitivanja odluke drugostepenog suda u sporovima koji nisu izuzetno velike vrednosti, sa ciljem da se smanji broj postupaka pred Vrhovnim kasacionim sudom, po osnovu ovog pravnog leka. ${ }^{5}$ Ovako postavljen novčani limit može se oceniti kao neopravdano visok, naročito kada se uporedi sa zakonskim rešenjima u regionu i nekim drugim evropskim državama. Revizijske sume u opštem parničnom postupku su sledeće: $\mathrm{BiH}$ (Federacija i Republika Srpska predviđaju iste iznose) - 10.000 konvertibilnih maraka (član 237. ZPP u oba entiteta); Crna Gora - 5.000 evra (član 397. stav 2. ZPP); Hrvatska - 100.000 kuna, što predstavlja protivvrednost od oko 15.000 evra (član 382. stav 1. tačka 1. ZPP); Makedonija - 500.000 denara, što predstavlja protivvrednost nešto višu od 8.000 evra (član 372. ZPP); Slovenija - po podatku koji mi je dostupan pre prelaska na evro, revizijska suma je iznosila 1.000.000 tolara, što bi odgovaralo protivvrednosti od oko 5.000 evra (član 367); Austrija: „\$502. Za dopuštenost revizije potrebno je da je vrednost predmeta spora prema drugostepenoj presudi u delu u kome revident nije uspeo u sporu veća od 5.000 evra, a vrednost predmeta spora u celini je preko 30.000 evra"; Nemačka: vrednost pobijanog dela drugostepene presude treba da bude viša od 20.000 evra. Već iz samih ovih iznosa može se zaključiti da je u parničnom postupku Vrhovni

5 Revizijski cenzus u ranije važećim odredbama iznosio je 2.500.000,00 dinara. Vidi: član 486. stav 1. Zakona o parničnom postupku. 
kasacioni sud postao teško dostupan strankama. U privrednim sporovima u Srbiji revizijska suma, kao što je navedeno, iznosi 300.000 evra u dinarskoj protivvrednosti na dan podnošenja tužbe. U državama u okruženju iznosi su sledeći: $\mathrm{BiH}$ (Federacija i RS imaju isto rešenje - nema posebnih pravila postupka za privredne sporove i nema posebne revizijske sume, što znači da važi režim iz opšteg parničnog postupka; Crna Gora - 25.000 evra; Hrvatska - 500.000 kuna (oko 75.000 evra); Makedonija - 1.000.000 denara (oko 16.200 evra); Slovenija - prema podatku kojim raspolažem, 5.000.000 tolara (oko 20.000 evra). Uporednopravno gledano, za Srbiju važi ista procena data povodom revizijske sume u opštem parničnom postupku.

2.3. Značajne promene uočavamo i kod postavljanja cenzusa za sporove male vrednosti, kako u građanskim tako i u privrednim sporovima. U građanskim parnicama male vrednosti dosadašnji iznos je zamenjen limitom od 3.000 evra u dinarskoj protivvrednosti na dan podnošenja tužbe, dok je ovaj iznos u privrednim sporovima 30.000 evra u dinarskoj protivvrednosti na dan podnošenja tužbe. Ove izmene omogućavaju da se veći broj sporova vodi po pravilima spora male vrednosti, što podrazumeva jednostavniju proceduru i brže okončanje postupka. ${ }^{6}$ Ali, sa druge strane, uporednopravno gledano, ovako visoko određeni iznosi ugrožavaju prava stranaka, s obzirom na sužene mogućnosti procene odbrane, napada, kao i pravnih lekova. Takođe, naročito kad je reč u sporovima male vrednosti pred privrednim sudovima, visoki limit od 30.000 evra znači da će mala i srednja preduzeća voditi mahom sporove male vrednosti, što za njih može predstavljati poseban rizik. ${ }^{7}$

6 Raniji cenzus je bio 100.000,00 dinara za građanski postupak i 300.000,00 dinara za postupak u privredi.

7 Sporovi male vrednosti - sud opšte nadležnosti

\begin{tabular}{|l|l|}
\hline Država & Iznos \\
\hline BiH (FBiH i RS isto) & 3.000 KM (1.500 evra) \\
\hline Crna Gora & 500 evra \\
\hline Hrvatska & 5.000 kuna (oko 750 evra) \\
\hline Makedonija & 60.000 denara (oko 650 evra) \\
\hline Slovenija & 200.000 tolara (oko 840 evra)? \\
\hline & \\
\hline
\end{tabular}

Sporovi male vrednosti - privredni sud

\begin{tabular}{|l|l|}
\hline Država & Iznos \\
\hline BiH (FBiH i RS, isto) & $\begin{array}{l}\text { Nema posebnog postupka za privredne sudove ni po- } \\
\text { sebne sume za sporove male vrednosti }\end{array}$ \\
\hline Crna Gora & 5.000 evra \\
\hline Hrvatska & 50.000 kuna (oko 7.500 evra) \\
\hline Makedonija & 300.000 denara (oko 3.250 evra) \\
\hline Slovenija & 500.000 tolara (oko 2.100 evra)? \\
\hline
\end{tabular}


2.4. U cilju bržeg i efikasnijeg rešavanja pokrenutih postupaka, izmene su pretrpele i odbredbe koje regulišu pokretanje sporova za zaštitu državine. Naime, nova rešenja u ovom pitanju ne predviđaju primenu odredaba ZPP-a o odgovoru na tužbu i pravilima o održavanju pripremnog ročišta. Iz ovoga se može zaključiti da se u parnicama čiji je predmet smetanje državine tužba ne šalje na odgovor, niti se održava pripremno ročište, iz navedenih razloga. Izmene su izvršene i u postupku za izdavanja platnog naloga, gde je limit postavljen u iznosu od 2.000 evra u dinarskoj protivvrednosti na dan podnošenja tužbe. U pogledu sporova male vrednosti povodom prigovora protiv platnog naloga, ranije postavljen iznos od 100.000,00 dinara zamenjen je protivvrednošću 3.000 evra na dan podnošenja tužbe. U slučaju preinačenja tužbe povećanjem zahteva iznad navedenog iznosa, postupak će se nastaviti i okončati po odredbama o redovnom postupku, dok će se u slučaju postavljanja tužbenog zahteva ispod navedenog iznosa, postupak voditi po pravilima spora male vrednosti.

\section{IZMENE KOJE SE ODNOSE NA POSTUPAK}

3.1. Kao što je istaknuto u uvodnom delu rada, jedan od ciljeva Zakona o izmenama i dopunama ZPP-a jeste reformisanje određenih delova postupka sa ciljem postavljanja jasnijih, ali i restriktivnijih pravila u određenim delovima postupka, kao i popunjavanje pravnih praznina. Jedna od suštinskih promena koja se reflektuje na celokupan postupak jeste mogućnost postavljanja ograničenja načelu raspravnosti, kao i mogućnost određivanja situacije u kojoj se odustaje od primene načela neposrednosti. ${ }^{8}$ Izmenama je uvedeno i načelo sudske istine u pravom smislu te reči, koje proklamuje da sud ne utvrđuje sve činjenice od kojih zavisi odluka o osnovanosti zahteva, već samo one na koje mu stranke ukažu i to samo na osnovu dokaza koje su same stranke predložile i koji su izvedeni u toku postupka. ${ }^{9}$ Time je pojačana dispozitivnost stranaka u pojedinim delovima postupka. Sud izuzetno može odstupiti od ovog načela kada je to izričito propisano ili kada utvrdi da stranke ne raspolažu zahtevima koji im nisu u nadležnosti.

8 U odredbama koje regulišu dokazni postupak, i to izvođenje dokaza saslušanjem stranaka, izvršene su promene tako što je predviđeno da: „u pozivu za ročište na kome će se izvoditi dokaz saslušanjem stranaka naznačiće se da stranka koja dođe na ročište može biti saslušana u odsustvu druge strane“. Navedeno zakonsko rešenje, odnosno mogućnost saslušanja stranke u odsustvu druge stranke postojala je i do sada i predstavlja odstupanja od raspravnog načela, ali se sada više potencira. To omogućava brži postupak i sprečava zloupotrebe. Vidi: Komentar Zakona o izmenama $i$ dopunama ZPP-a.

9 Ovo je postignuto terminološkom izmenom u članu 7. stav 2. ZPP-a. Vidi: član 4. Zakona o izmenama i dopunama ZPP-a. 
3.2. S obzirom na probleme koji su se javljali u pogledu primene člana 6. ZPP-a, izmenama je izričito proklamovano korišćenje ćiriličnog pisma u službenoj upotrebi, uz pravo manjina na teritoriji Republike Srbije da se služe svojim jezikom i pismom, o kome će ih poučiti sud, a koje je bilo sadržano i u prethodno važećim odredbama. Novinu predstavljaju pravila koja regulišu prava slepih, gluvih i nemih stranaka i učesnika u postupku na besplatnog tumača u postupku pred sudom, da bi im se omogućilo da zbog specifičnosti svojih potreba isti postupak prate. ${ }^{10}$

3.3. Zakon je uneo je značajne modifikacije i u postavljanju pravila za određivanje sastava suda u sporovima. Za razliku od ranijeg rešenja, gde je za sporove koji se odnose na zaštitu ili upotrebu pronalazaka i tehničkog unapređenja uzoraka modela žigova ili geografskih oznaka porekla, prava na upotrebu firme ili naziva, kao i zaštitu autorskih i srodnih prava bilo predviđeno suđenje u veću, Zakon postavlja određivanje sastava suda u odnosu na vrednost spora. Tako je utvrđeno da sudija pojedinac sudi u sporovima vrednosti do 50.000 evra u dinarskoj protivvrednosti na dan podnošenja tužbe, s tim što se stranke mogu sporazumeti da pojedinac sudi i u sporovima preko te vrednosti. Ovde uočavamo još jedan primer proširenja stranačkih ovlašćenja u parničnom postupku. Sastav drugostepenog suda pri odlučivanju na sednici veća ili raspravi, sada čini veće od trojice sudija. Ovo pravilo se odnosi na sva pitanja u drugostepenom odlučivanju, sa izuzetkom spora o sukobu nadležnosti, gde se tumačenjem dolazi do zaključka da može suditi sudija pojedinac. ${ }^{11}$ Vrhovni kasacioni sud takođe sudi u veću od trojice sudija, po vanrednim pravnim lekovima. Ovo smanjenje sastava veća trećestepenog suda uvedeno je radi bržeg i efikasnijeg postupanja, kao i iz razloga smanjenja broja sudija u Vrhovnom kasacionom sudu. ${ }^{12}$

3.4. Značajna ovlašćenja ustanovljena su u korist sudskih pomoćnika da samostalno, radi pripreme za preduzimanje potrebnih mera i odluka predviđenih u okviru prethodnog ispitivanja tužbe, odnosno radi organizovanja pripremnog ročišta i prvog ročišta za glavnu raspravu, obave poslove prethodnog ispitivanja tužbe. U duhu ZPP-a, međutim, bolje je bilo upotrebiti izraz „parnične radnje“ nego „poslovi“. Do sada ove radnje nisu mogli obavljati sudijski pomoćnici, već isključivo sudije shodno izričitim odredbama ZPP-a.

\section{Vidi: Komentar Zakona o izmenama i dopunama ZPP-a.}

11 U izuzetak ne spada predlog za delegaciju drugog suda. Inače, u ovom delu zakona koji reguliše pitanje delegacije načinjena je značajna izmena u odnosu na ranije važeće zakonsko rešenje. Razlozi zbog kojih se odbacuje predlog za određivanje drugog stvarno nadležnog suda prošireni su, i to tako što se pored odbacivanja predloga koji je istovetan ranije podnetom, sada odbačaj predloga predviđa i u situacijama ako je predlog neobrazložen ili ne sadrži razloge zbog kojih se traži delegacija drugog suda, kao i ako stranka traži određivanje drugog stvarno nadležnog suda iz razloga koji se odnose na isključenje odnosno izuzeće. Vidi: Komentar Zakona o izmenama i dopunama ZPP-a.

12 Ranijim rešenjem se predviđalo veće od petoro sudija. 


\section{IZMENE KOJE SE ODNOSE NA POSTUPAK PO PRAVNIM LEKOVIMA}

4.1. Pravni lekovi predstavljaju značajne pravne instrumente u rukama stranaka, koji im dozvoljavaju pobijanje sudske odluke pre (redovni pravni lekovi), kao i nakon njene pravnosnažnosti (vanredni pravni lekovi). Karakteristika ovih pravnih instrumenata jeste da su njihove vrste, kao i uslovi za primenu, precizno određeni kako bi se izbegle nejasnoće i pravne praznine.

4.2. Izmene u postupku po pravnim lekovima sadržane su u proširenju odredbe ZPP-a kojoj je dodato pravilo da se prvostepena presuda koja je već jednom bila ukinuta ne može ponovo ukidati i vraćati prvostepenom sudu na ponovno suđenje. Ukoliko je odluka prvostepenog suda bila ukinuta, bilo kada i po bilo kom zakonu o parničnom postupku, drugostepeni sud ima obavezu da meritorno odluči o zahtevu. ${ }^{13}$ Kao posledica predviđanja instrumenta ustavne žalbe, uvedeno je još jedno značajno proširenje u pogledu mogućnosti isticanja zahteva za ponavljanje postupka. Prema novom rešenju, postupak koji je pravnosnažno završen može se po predlogu stranke ponoviti i ako je u toku postupka po ustavnoj žalbi Ustavni sud utvrdio povredu ili uskraćivanje ljudskog ili manjinskog prava i slobode zajemčene Ustavom u parničnom postupku. ${ }^{14}$

\subsection{Dozvoljenost revizije po Zakonu o izmenama i dopunama ZPP-a}

4.3.1. Revizija kao oblik vanrednog pravnog leka podnosi se protiv pravnosnažne sudske presude donesene $\mathrm{u}$ drugom stepenu u roku od 30 dana od dana dostavljanja prepisa presude. Revizija je dozvoljena kad to proceni apelacioni sud (1. januara 2010. godine), dok je vrednost predmeta spora relevantna kada se radi o imovinskopravnim sporovima. Zakonom o izmenama i dopunama ZPP-a unete su određene izmene i proširenja navedenih pravila vezanih za reviziju. Vrednost predmeta spora pobijanog dela presude relevantna je i kada se tužbeni zahtev odnosi na utvrđenje prava svojine (pored potraživanja $\mathrm{u}$ novcu, predaje stvari ili izvršenja neke druge činidbe). Kao što je istaknuto u delu o limitima novčanih vrednosti, novčani iznos vrednosti predmeta spora i način izračunavanja jeste dinarska protivvrednost 100.000 evra po srednjem kursu Narodne banke Srbije na dan podnošenja tužbe (u privrednim sporovima 300.000 evra). ${ }^{15}$ Dozvoljenost revizije van revizijskih limita je sužena, te je revizija dozvoljena još samo onda kada je to posebnim zakonom određeno.

13 Vidi: član 36. Zakona o izmenama i dopunama ZPP-a.

14 Vidi: član 41. Zakona o izmenama i dopunama ZPP-a.

15 Vidi: član 38. Zakona o izmenama i dopunama ZPP-a. 


\section{ZAKLJUČAK}

U kratkoj analizi izloženoj u tekstu uočavamo da, naizgled oskudne, izmene ZPP-a obuhvataju različite segmente postupka i u nekim slučajevima bitno utiču na postavljena prava stranaka, kao i na sam tok postupka. Iz izloženih rešenja Zakona o izmenama i dopunama Zakona o parničnom postupku uočavamo suštinu ciljeva koje je zakonodavac hteo da postigne. Pored objektivne potrebe za terminološkim i praktičnim usklađivanjem normativnih rešenja sa izmenjenim rešenjima u drugim zakonima, jedan od razloga predviđanja novih rešenja jeste obezbeđivanje bržeg i efikasnijeg suđenja. U ove svrhe uvedene su promene u sastavu sudskih veća, kao posledica reforme sudstva, kao i postavljanje granice vrednosti spora za suđenje sudije pojedinca i za određenje karaktera spora male vrednosti. Postavljanje svih iznosa u stranoj valuti, tj. evrima, naizgled se čini nelogičnim. Međutim, takvo određenje ima za cilj da predupredi moguću inflaciju. Ograničenja uspostavljena visokim sumama, međutim, mogu da ugroze prava stranaka na upotrebu vanrednih pravnih lekova i na pristup Vrhovnom kasacionom sudu. Takođe, sužavanje mogućnosti izjavljivanja revizije neće pogodovati ujednačavanju sudske prakse. 